\title{
Synthesis of 1,3-Oxazolidines and 1,2-Amino Alcohols from $N$-Tosylimines Using Rh(II) Catalyst in Acetone ${ }^{\dagger}$
}

\author{
Nam-Sun Kim, Se-Youn Kang, and Seung-Han Lee* \\ Department of Applied Chemistry, Kyung Hee University, Yongin 446-701, Korea \\ Received October 23, 2009, Accepted December 11, 2009
}

Key Words: Oxazolidine, Amino alcohol, Carbonyl ylide, Rh(II) catalyst, Multi-component reaction

1,3-Oxazolidines and 1,2-amino alcohols are widely used as chiral auxiliaries to direct diastereoselective transformations and as intermediates in organic synthesis. ${ }^{1}$ We reported the formation of 1,3-oxazolidines and 1,2-amino alcohols from imines using diazoacetate (EDA) and metal catalysts. ${ }^{2}$ In this study, we demonstrate that 1,3-oxazolidines and 1,2-amino alcohols can be generated by reaction of $N$-tosylimines with EDA using $\mathrm{Rh}$ (II) catalyst in dry acetone and aqueous acetone, respectively.

A number of experiments were performed to maximize the efficiency of the 1,3-oxazolidine forming reaction. The reactions of imines with EDA ( 2 equivalents) using $1 \% \mathrm{Rh}_{2}(\mathrm{OAc})_{4}$ in dry acetone afforded the oxazolidines in moderate to high yields (Scheme 1, Table 1). ${ }^{3}$

The imines with an electron-withdrawing substituent at the

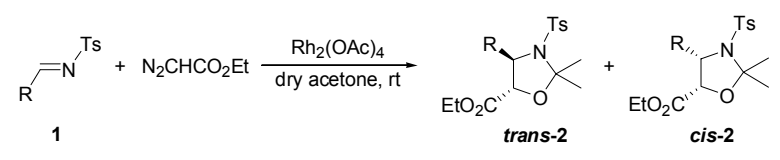

Scheme 1

Table 1. $\mathrm{Rh}(\mathrm{II})$-catalyzed 1,3-oxazolidine formation in dry acetone

\begin{tabular}{|c|c|c|c|c|c|}
\hline entry & imine & $\mathrm{R}$ & $\begin{array}{l}\text { EDA } \\
\text { (equiv) }\end{array}$ & $\begin{array}{l}\text { catalyst } \\
(\mathrm{mol} \%)\end{array}$ & $\begin{array}{c}2(\%)^{a} \\
\left(\text { trans }^{2} \text { cis }\right)^{b}\end{array}$ \\
\hline 1 & $1 \mathrm{a}$ & $\mathrm{Ph}$ & 2 & 1 & $86(1.1)$ \\
\hline 2 & $1 b$ & $p-\mathrm{NO}_{2} \mathrm{Ph}$ & 2 & 1 & $97(1.1)$ \\
\hline 3 & $1 \mathrm{c}$ & $p$-ClPh & 2 & 1 & 95 (1.6) \\
\hline 4 & 1d & $p-\mathrm{CH}_{3} \mathrm{OPh}$ & 2 & 1 & $39(1.2)$ \\
\hline 5 & 1d & $p-\mathrm{CH}_{3} \mathrm{OPh}$ & 2 & 3 & $51(1.2)$ \\
\hline 6 & 1d & $p-\mathrm{CH}_{3} \mathrm{OPh}$ & 4 & 3 & $65(1.2)$ \\
\hline 7 & $1 e$ & $o-\mathrm{CH}_{3} \mathrm{OPh}$ & 4 & 3 & $72(1.2)$ \\
\hline 8 & 1f & $p-\mathrm{CH}_{3} \mathrm{Ph}$ & 2 & 1 & $47(1.1)$ \\
\hline 9 & 1f & $p-\mathrm{CH}_{3} \mathrm{Ph}$ & 2 & 3 & $64(1.1)$ \\
\hline 10 & 1f & $p-\mathrm{CH}_{3} \mathrm{Ph}$ & 4 & 3 & $93(1.4)$ \\
\hline 11 & $1 g$ & Furanyl & 2 & 1 & $61(1.3)$ \\
\hline 12 & 1h & $n$-Butyl & 2 & 3 & $46(1.1)$ \\
\hline 13 & $1 \mathbf{i}$ & tert-Butyl & 2 & 3 & No reaction \\
\hline 14 & $\mathbf{1 j}$ & $\mathrm{PhCH}=\mathrm{CH}-$ & 2 & 1 & $29(1.2)$ \\
\hline 15 & $\mathbf{1 j}$ & $\mathrm{PhCH}=\mathrm{CH}-$ & 2 & 3 & $39(1.4)$ \\
\hline 16 & $1 \mathrm{j}$ & $\mathrm{PhCH}=\mathrm{CH}-$ & 4 & 3 & $67(1.2)$ \\
\hline
\end{tabular}

${ }^{a}$ Isolated yields. ${ }^{b}$ Ratios were determined by ${ }^{1} \mathrm{H}$ NMR analysis.

${ }^{\dagger}$ This paper is dedicated to Professor Sunggak Kim on the occasion of his honorable retirement. phenyl ring resulted in higher yields than the imines with an electron-donating substituent at the phenyl ring (Table 1, entries 2 and $3 v s .4$ and 8 ). ${ }^{4}$ In the cases of imines with the electrondonating substituent at the phenyl ring, increases in the amounts of Rh(II) catalyst and EDA improved the yield (Table 1, entries 6,7 , and 10). Other aryl and alkyl-substituted imines also furnished the corresponding oxazolidines in moderate yields (Table 1, entries 11 and 12). However, the sterically bulky tert-butylsubstituted imine gave no reaction (Table 1, entry 13). With imine derived from cinnamaldehyde, the reaction with EDA resulted in only five-membered oxazolidine $\mathbf{2 j}$ (Table 1 , entries 14-16). ${ }^{5 \mathrm{a}}$

The ratio of cis- to trans-oxazolidines produced in these reactions varied from 1.1 to 1.6 , as determined by ${ }^{1} \mathrm{H}-\mathrm{NMR}$. The structures of the 1,3-oxazolidine products were determined using ${ }^{1} \mathrm{H}$ - and ${ }^{13} \mathrm{C}$-NMR spectroscopy. ${ }^{2}$ Since the reaction yields diethyl maleate and fumarate as side products formed from the carbene complex, the reaction involves intermediate carbonyl ylide A or azomethine ylide B (Scheme 2). ${ }^{5,6}$ The ${ }^{1} \mathrm{H}$ NMR spectrum of the trans-diastereomer of oxazolidine $2 \mathbf{a}$ contained two singlets $(1.78(3 \mathrm{H})$ and $1.86(3 \mathrm{H}) \mathrm{ppm})$ assigned to the methyl groups at $\mathrm{C}-2$ and two doublets $(4.48(1 \mathrm{H}, J=5.2 \mathrm{~Hz})$ and $5.17(1 \mathrm{H}, J=5.2 \mathrm{~Hz}) \mathrm{ppm})$ corresponding to the vicinally disposed ring protons. Therefore, the reaction proceeds via the carbonyl ylide intermediate since the azomethine ylide intermediate produces the wrong product. The regiochemistry of the reaction can be rationalized in terms of maximum overlap of the dipole HOMO-dipolarphile LUMO, as is the case with carbonyl ylide cycloadditions. ${ }^{4}$

The amino alcohols 3 were prepared from the hydrolysis of $\mathrm{N}$-tosyl-1,3-oxazolidines using $6 \mathrm{~N} \mathrm{HCl}$ in acetone at moderate yields (syn-3a; $\mathrm{R}=\mathrm{Ph} 81 \%$, syn-3b; $\left.\mathrm{R}=p-\mathrm{NO}_{2} \mathrm{Ph} 74 \%\right)(\mathrm{Sch}-$ eme 3).

The hydrolysis reaction was stereospecific in which transoxazolidines yielded the syn-amino alcohols and cis-oxazol-

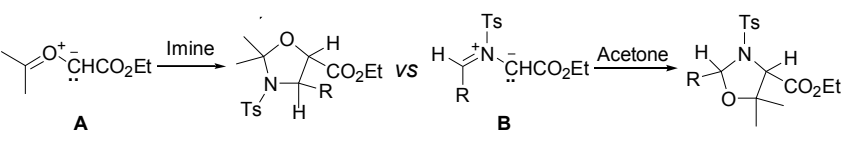

Scheme 2



Scheme 3 


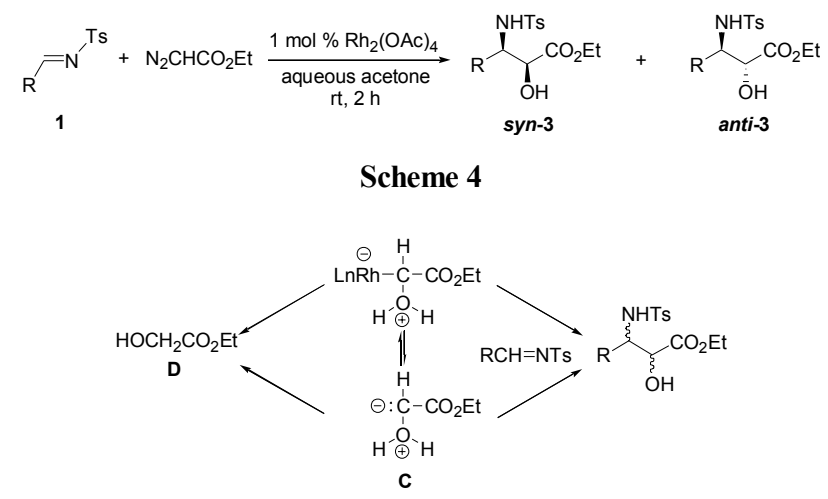

Scheme 5

Table 2. Rh(II)-catalyzed 1,2-amino alcohol formation in aqueous acetone

\begin{tabular}{clccc}
\hline entry & imine $\mathrm{R}$ & $\begin{array}{c}\mathrm{EDA} \\
\text { (equiv) }\end{array}$ & $\begin{array}{c}\text { recovered } \\
\text { Imine (\%) }\end{array}$ & $\begin{array}{c}\mathbf{3}(\%)^{a} \\
(\text { anti/syn) }\end{array}$ \\
\hline 1 & $\mathrm{Ph}$ & 2 & 10 & $78(2.8)$ \\
2 & $\mathrm{Ph}$ & 4 & - & $95(2.8)$ \\
3 & $p-\mathrm{NO}_{2} \mathrm{Ph}$ & 2 & - & $89(4.2)$ \\
4 & $p-\mathrm{NO}_{2} \mathrm{Ph}$ & 4 & - & $94(4.5)$ \\
5 & $o-\mathrm{NO}_{2} \mathrm{Ph}$ & 2 & 4 & $81(2.5)$ \\
6 & $p-\mathrm{CNPh}_{7}$ & 2 & - & $84(6.0)$ \\
7 & $p-\mathrm{ClPh}$ & 2 & 15 & $63(1.7)$ \\
8 & $p-\mathrm{CH}_{3} \mathrm{Ph}$ & 2 & 41 & $48(1.8)$ \\
9 & $p-\mathrm{CH}_{3} \mathrm{Ph}$ & 4 & 33 & $65(1.8)$ \\
10 & $p-\mathrm{CH}_{3} \mathrm{OPh}$ & 2 & 62 & $26(1.4)$ \\
11 & $p-\mathrm{CH}_{3} \mathrm{OPh}$ & 2 & 50 & $40(1.4)$ \\
12 & $2-\mathrm{Naphthyl}_{12}$ & 2 & 19 & $65(1.8)$ \\
13 & $2-\mathrm{Furanyl}$ & 2 & 37 & $61(1.8)$ \\
14 & $n-\mathrm{Butyl}$ & 2 & 8 & $11(1.1)$ \\
\hline
\end{tabular}

${ }^{a}$ Isolated yields. ${ }^{b}$ Ratios were determined by ${ }^{1} \mathrm{H}$ NMR analysis.

idines yielded the anti-amino alcohols.

Since amino alcohols were produced during the 1,3-oxazolidines forming reaction from imines and ethyl diazoacetate (EDA) using copper catalysts in our previous work, ${ }^{2 \mathrm{a}}$ we attempted a Rh(II) catalyzed reaction in aqueous acetone (Scheme 4). These reactions produced a mixture of $s y n$ - and anti-1,2-amino alcohols at moderate to high yields (Table 2).

The reaction shows the same substituent effect as the 1,3oxazolidine forming reaction. The imines with an electronwithdrawing substituent at the carbon had higher yields than the imines with the electron-donating substituent at the carbon. The ratio of anti- to syn-amino alcohols varied from 1.1 to 6.0, as determined by ${ }^{1} \mathrm{H}-\mathrm{NMR}$.

The reaction may proceed via aziridine, oxazolidine, azomethine ylide $\mathbf{B}$, or oxonium ylide intermediate $\mathbf{C}$. However, the ring-opening reaction of aziridine or the attempted hydrolysis of 1,3-oxazolidine using Rh(II) catalyst in aqueous acetone resulted in no reaction. Small amounts of diethyl maleate and fumarate resulting from the dimerization of the corresponding carbene and ethyl ester of hydroxyacetic acid $\mathbf{D}$ were formed from the insertion of EDA in the $\mathrm{O}-\mathrm{H}$ bonds of water. ${ }^{7}$ These combined results suggest that water reacts with the carbene complex to form oxonium ylide $\mathbf{C}$ followed by imine addition to yield the product (Scheme 5). ${ }^{8}$

In summary, 1,3-oxazolidines and 1,2-amino alcohols were prepared at moderate to high yields from $N$-tosylimines and EDA using Rh(II) catalyst in dry acetone or aqueous acetone, respectively. Also, 1,2-amino alcohols were prepared stereospecifically at high yields by the hydrolysis of $N$-tosyl-1,3oxazolidines using $6 \mathrm{~N} \mathrm{HCl}$ in acetone.

Acknowledgments. This work was supported by a grant from Kyung Hee University in 2005 (KHU-20050362).

\section{References}

1. (a) Ager, D. J.; Prakash, I.; Schaad, D. R. Chem. Rev. 1996, 96, 835. (b) Le Bail, M.; Perard, J.; Aitken, D. J.; Bonin, M.; Husson, H.-P. Tetrahedron Lett. 1997, 38, 7177. (c) Shen, M.; Li, C. J. Org. Chem. 2004, 69, 7906. (d) Kang, Y.-F.; Wang, R.; Liu, L.; Da, C.-S.; Yan, W.-J.; Xu, Z.-Q. Tetrahedron Lett. 2005, 46, 863.

2. (a) Lee, S.-H.; Yang, J.; Han, T.-D. Tetrahedron Lett. 2001, 42, 3487. (b) Lee, S.-H.; Kim, Y.-H. Bull. Korean Chem. Soc. 2005, 26,225 .

3. General procedure for oxazolidine formation from $N$-tosylimine. Under a nitrogen atmosphere, $N$-tosylimine $(0.5 \mathrm{mmol}, 1.0$ equiv $)$ was added to a stirred solution of $\mathrm{Rh}_{2}(\mathrm{OAc})_{4}(0.005 \mathrm{mmol}, 0.01$ equiv) in dry acetone $(5 \mathrm{~mL})$ at room temperature. After stirring for $30 \mathrm{~min}$, ethyl diazoacetate ( $1.0 \mathrm{mmol}, 2.0$ equiv) was added. After stirring for $2 \mathrm{~h}$, the reaction mixture was concentrated, dissolved in ether, and filtered through celite. The ethereal solution was concentrated in vacuo and chromatographed on silica gel (EA : hexane $=1: 4)$.

trans-5-Ethyloxycarbonyl-2,2-dimethyl-4-phenyl-3-( $p$-toluenesulfonyl)-1,3-oxazolidine (trans-2a): IR (KBr) 2994, 2965, 2940, $1753,1597,1344,1213,1160 \mathrm{~cm}^{-1} ;{ }^{1} \mathrm{H} \mathrm{NMR}\left(400 \mathrm{MHz}, \mathrm{CDCl}_{3}\right)$ $\delta 7.39(\mathrm{~d}, J=8.0 \mathrm{~Hz}, 2 \mathrm{H}), 7.23-7.14(\mathrm{~m}, 5 \mathrm{H}), 7.04(\mathrm{~d}, J=8.0 \mathrm{~Hz}$, $2 \mathrm{H}), 5.17(\mathrm{~d}, J=5.2 \mathrm{~Hz}, 1 \mathrm{H}), 4.48(\mathrm{~d}, J=5.2 \mathrm{~Hz}, 1 \mathrm{H}), 4.17(\mathrm{q}, J=$ $6.8 \mathrm{~Hz}, 2 \mathrm{H}), 2.33(\mathrm{~s}, 3 \mathrm{H}), 1.86(\mathrm{~s}, 3 \mathrm{H}), 1.78(\mathrm{~s}, 3 \mathrm{H}), 1.22(\mathrm{t}, J=$ $7.2 \mathrm{~Hz}, 3 \mathrm{H}) ;{ }^{13} \mathrm{C}$ NMR $\left(100 \mathrm{MHz}, \mathrm{CDCl}_{3}\right) \delta 169.76,142.93$, $137.86,137.65,128.86,128.19,127.76,127.47,127.40,100.29$, $81.74,65.19,61.76,28.97,26.96,21.45,14.08$.

cis-5-Ethyloxycarbonyl-2,2-dimethyl-4-phenyl-3-(p-toluenesulfonyl)-1,3-oxazolidine (cis-2a): IR (KBr) 2985, 2940, 1760, 1594, $1460,1338,1211,1153 \mathrm{~cm}^{-1} ;{ }^{1} \mathrm{H} N \mathrm{MR}\left(400 \mathrm{MHz}, \mathrm{CDCl}_{3}\right) \delta 7.27$ $(\mathrm{d}, J=8.4 \mathrm{~Hz}, 2 \mathrm{H}), 7.13-7.04(\mathrm{~m}, 5 \mathrm{H}), 6.92(\mathrm{~d}, J=8.4 \mathrm{~Hz}, 2 \mathrm{H})$, $5.10(\mathrm{~d}, J=7.2 \mathrm{~Hz}, 1 \mathrm{H}), 5.03(\mathrm{~d}, J=7.2 \mathrm{~Hz}, 1 \mathrm{H}), 3.82-3.65(\mathrm{~m}$, $2 \mathrm{H}), 2.26(\mathrm{~s}, 3 \mathrm{H}), 1.95(\mathrm{~s}, 3 \mathrm{H}), 1.85(\mathrm{~s}, 3 \mathrm{H}), 0.78(\mathrm{t}, J=7.2 \mathrm{~Hz}, 3 \mathrm{H})$; ${ }^{13} \mathrm{C}$ NMR $\left(100 \mathrm{MHz} \mathrm{CDCl}_{3}\right) \delta 166.80,143.21,137.62,136.50$, 129.03, 128.56, 128.13, 128.01, 127.72, 98.89, 77.65, 64.19, 61.32, 26.61, 26.28, 21.54, 13.70 .

4. (a) Padwa, A.; Precedo, L.; Semones, M. A. J. Org. Chem. 1999, 64, 4079. (b) Benchouk, W.; Mekelleche, S. M.; Aurell, M. J.; Domingo, L. R. Tetrahedron 2009, 65, 4644.

5. (a) Doyle, M. P.; Hu, W.; Timmons, D. J. Org. Lett. 2001, 3, 933. (b) Hodgson, D. M.; Pierard, F. Y. T. M.; Stupple, P. A. Chem. Soc. Rev. 2001, 30, 50. (c) Doyle, M. P.; Forbes, D. C.; Protopopova, M. N.; Stanley, S. A.; Vasbinder, M. M.; Xavier, K. R. J. Org. Chem. 1997, 62, 7210

6. (a) Doyle, M. P.; Yan, M.; Hu, W.; Gronenberg, L. S. J. Am. Chem. Soc. 2003, 125, 4692. (b) Rasmussen, K. G.; Jørgensen, K. A. J. Chem. Soc. Perkin Trans. 1 1997, 1287.

7. R. Paulissen; Reimlinger, H.; Hayez, E.; Hubert, A. J.; Teyssié, $\mathrm{Ph}$. Tetrahedron Lett. 1973, 24, 2233.

8. (a) Huang, H.; Guo, X.; Hu, W. Angew. Chem. Int. Ed. 2007, 46, 1337. (b) Lu, C.-D.; Liu, H.; Chen, Z.-Y.; Hu, W.-H.; Mi, A.-Q. Org. Lett. 2005, 7, 83. (c) Zhang, X.; Huang, H.; Guo, X.; Guan, X.; Yang, L.; Hu, W. Angew. Chem. Int. Ed. 2008, 47, 6647. (d) Xu, X.; Zhou, J.; Yang, L.; Hu, W. Chem. Commun. 2008, 6564. 